DOI: 10.33766/2524-0323.92.245-257

УДК 351

М. В. Федоренко,

здобувач ступеню вищої освіти «магістр»

Національної академії державного управління при Президентові України

(м. Київ, Україна)

e-mail:lermont98@gmail.com.

iDhttps://orcid.org/0000-0003-4392-7124

\title{
УТВЕРДЖЕННЯ, РОЗВИТОК ТА ОСНОВНІ НАПРЯМКИ УДОСКОНАЛЕННЯ СИСТЕМ УПРАВЛІННЯ ДЕРЖАВНОЮ СЛУЖБОЮ В УКРАЇНІ ТА РЕСПУБЛІЩ ПОЛЬЩА
}

У статті розкривається сутність, зміст і особливості побудови і функціонування системи управління державною (публічною) службою в Україні та в Республіці Польща в трансформаційний період. Систематизується позитивний досвід моделювання ефективної системи управління публічною (цивільною) службою в Польщі, який може бути використаним в Україні для розв'язання проблем. Розкривається генезис та еволюція інституту управління державною службою в Україні, а також зміст й особливості трансформації системи управління державної служби в контексті проведення реформи публічної служби в 2015-2020 роках. Здійснюється порівняння та аналіз правового й управлінського статусу основних елементів (суб'єктів) системи управління державною службою в Україні та Республіщі Польщі. Аналізується призначення центрів (шкіл, академій) для професійної підготовки, перепідготовки, спеціалізації та підвищення кваліфікації державних службовців в Україні та Польщі на прикладі Національної академії державного управління при Президентові України (НАДУ) та Державної школи адміністрації публічної ім. Президента Республіки Польської Лєха Качинського.

Ключові слова: державна служба, цивільна служба, система управління державною службою, реформа державної служби.

Постановка проблеми. Розвиток України як успішної європейської держави залежить насамперед від успіхів реформування публічного управління та публічної служби в трансформаційний період. Саме професійний і доброчесний корпус державних службовців покликаний стати провідником прогресивних змін у суспільстві та державі. Причому, загалом позитивна реформа державної служби (розмежування політичних та адміністративних посад; запровадження конкурсів на всі вакантні посади державної служби, утвердження інституту державних секретарів тощо), проведена в Україні в 2015-2019 роках, на сьогодні, у 2020 році, потребує переосмислення своїх результатів і здобутків, а також визначення нових цілей і пріоритетів свого подальшого розвитку. Зокрема, у частині удосконалення механізмів організації та діяльності системи управління державною службою в Украӥні, 3 урахуванням кращих практик держав-учаснищь Європейського Союзу. Найбільш близьким і зрозумілим для України є досвід творення цивільної служби в Республіці Польща.

( ) Федоренко М. В., 2020 
Не менш важливим для теорії та практики публічної служби в Україні є на сьогодні й конструктивна відповідь на глобальний виклик щодо забезпечення ефективного управління у сфері формування та забезпечення ефективного управління державною службою в умовах подолання пандемії коронавірусу COVID - 2019. Очевидно, що процедури тимчасового добору на державну службу на період карантину [19] лише фрагментарно розв'язують цю проблему й на сьогодні піддаються гострій критиці з боку СС [3]. Ці та інші питання організації та функціонування системи управління державною службою в Україні потребують свого нагального вирішення на основі відповідних наукових напрацювань і врахування позитивного зарубіжного досвіду. Оскільки за основу реформування державної служби в Україні за останні п'ять років був узятий досвід феноменології «творення цивільної служби» в Республіці Польща, слушним буде проаналізувати й порівняти системи управління державною службою в Україні та Республіці Польща.

Аналіз останніх досліджень і публікацій. Проблематика державної служби зберігає свою актуальність насамперед у конституційному та адміністративному праві, у державному управлінні та інших соціогуманітарних науках (історія держави і права, соціологія та ін). На сьогодні дослідники проблем теорії та практики державної служби досліджують питання стосовно до проблем теорії та методології дослідження публічної служби (М. Білинська [2], С. Хаджирадєва [15]); планування та прогнозування кадрової політики (Р. Войтович [5]); реформування публічної служби (О. Пухкал [16]); механізмів утвердження та захисту конституційного права на доступ до державної служби та проходження державної служби в Україні (А. Малюга [9]); взаємодії державних службовців з групами громадськості (В. Нестерович $[24,25])$; організаційно-правового забезпечення проходження державної служби в Україні та відповідальність державних службовців (С. Дубенко [6], Д. Неліпа [10]) тощо. Інститут державної служби також порівнюється з аналогічними інститутами за кордоном, насамперед, у державах-учаснищях ЄС, включаючи Польщу (М. Денисов [4], Д. Красівський [8], К. Проскуряков [14] та ін.), у тому числі, і в попередніх публікаціях автора [18].

При підготовці цієї публікації також були проаналізовані роботи наступних польських учених, які досліджували питання державної служби: Д. Боссаерт і Х. Деммке «Цивільна служба в об'єднаних державах. Тенденції і вплив процесів інтеграційних» [20], Габермас Я. «Структурні трансформації публічної сфери» [22], Б. Кудрицька «Розвиток кадрів адміністрації публічної» [23], Б. Пшивора «Трансформація устрою польської служби цивільної» [27] і ін. До уваги були прийняті й важливі, але на сьогодні дещо підзабуті напрацювання (нариси) 3 історії управління публічною службою в Україні та Речі Посполитій із IX до поч. XX ст. Зокрема, роботи М. Загосіна «Нариси організації та походження служилого стану в допетрівській Русі» [7], Л. Ольшевського «Бюрократія» [11], «Сборник распоряжений Графа Михаила Николаевеча Муравьева по усмирению Польского мятежа в Северо-Западных губерний 1863-1864» [17] та ін. 
Водночас, проблематика генезису і функціонування системи управління державною службою в Україні, з урахуванням сучасного позитивного досвіду творення цивільної служби в Польщі, у контексті новітніх трансформаційних процесів, залишається малодослідженою й заслуговує на увагу учених.

Формулювання цілей. Метою статті є формування конщептуальних підходів до утвердження, розвитку та удосконалення побудови і функціонування систем управління державною (цивільною) в Україні та Республіці Польща, а також виявлення шляхів і методів удосконалення вітчизняних механізмів реалізації державної кадрової політики, на основі сучасного позитивного польського досвіду.

Викладення основного матеріалу. Усталені в XXI ст. погляди на державну службу як спеціальний режим здійснення громадянами, наділеними відповідною компетенцією, функцій держави, або ж як про корпус державних службовців, що забезпечують правосуб' єктність держави, реалізацію їі внутрішніх і зовнішніх функцій дають найбільш загальні уявлення про цей важливий для суспільства та держави інститут. Водночас, державна служба, як і будь-який ресурсоємкий інститути державного управління, вимагає свого раціонального та ефективного використання в інтересах народу та держави.

На наш погляд, управління державною службою - це визначена Конституцією та законами України, насамперед спеціальним Законом України «Про державну службу», цілеспрямована, розпорядча, організаційно-владна діяльність органів державної влади, спрямована на: 1) визначення, унормування та реалізацію єдиної державної кадрової політики у сфері державної служби, із широким залученням громадськості; 2) імплементація міжнародних стандартів у сфері публічної служби (міжнародні договори, зокрема, Угода про асоціацію України і СС; рекомендації Ради Свропи і СC; оціночні документи SIGMA, документи TAIEX та ін.; рішення Європейського Суду з прав людини (ССПЛ) щодо захисту рівного права на доступ до державної служби й ін.); 3) утвердження комплексної та збалансованої системи управління державною службою, репрезентованої суб'єктами, які: а) формують державну політику у сфері публічної служби, з урахуванням міжнародних стандартів; б) реалізують державну кадрову політику та положення чинного законодавства, стратегій і програм з питань державної служби; в) забезпечують підготовку, перепідготовку та підвищення кваліфікації корпусу державної служби; 4) формування та перманентне оновлення освіченого, високопрофесійного, патріотичного та доброчесного корпусу державної служби, що здійснюється транспарентно, на конкурсних засадах; 5) упередження конфлікту інтересів, неопотизму, «кумівства» та будь-яких проявів корупщії під час вступу на державну службу та впродовж усього часу їі проходження; 6) організація безперервної, упродовж усієї кар'єри державного службовця, його професійної підготовки, перепідготовки, спеціалізації та підвищення кваліфікації 7) забезпечення соціального та правового захисту державних службовців, підвищення престижу державної служби в суспільсті та державі.

Своєю чергою, система управління державною службою - це встановлена чинним законодавством ієрархія супідрядних та узгоджено функціонуючих 
суб'єктів державного управління, а також система завдань, функцій і повноважень, методів, форм і механізмів щодо формування та реалізації кадрової політики у сфері державної служби. ІІї ключовими ознаками є: а) легальність і легітимність; б) врахування національних традицій та міжнародних стандартів управління публічною службою; в) ієрархічність (т. зв. «кадрова вертикаль») у поєднанні з демократичним характером; г) єдиноначальність у поєднанні 3 колегіальністю; г) усебічність і повсюдність дії на всій території держави; інтегрованість у національну систему органів державної виконавчої влади з охопленням державної служби в парламенті, офісі (канцелярії) глави державу та в адміністраціях судової влади еtс.

Будучи спорідненими, системи органів управління державною службою в Україні та Польщі пройшли тривалий, і багато в чому подібний генезис та еволюціонування з IX ст. Свого часу, у сер. XIX ст., німецький учений Г. Аренс писав: «Слов'яни з'являються розділеними на два великих племені, одне з яких називалося тоді Слов'янами, а інші - Антами. Тепер ці племена, за їх місцем проживання і за народами, що їх складають, утворюють дві галузі: Богемо-Польську, або Північно-Західну, до якої належать Морави, Чехи, Ляхи або Поляки і Венди, у тісному зв'язку, і Русько-Сербську, що також називається Русько-Іллірійською, або Південно-Східну, до якої належать Руські, тобто Великороси, Малороси, Русняки (Русини або Рутени), Болгари і різноманітні племена Іллірійських Слов'ян. Між Германцями і Слов'янами в мові та характері більше схожості, аніж між Германцями і Кельтами; але слов' янський характер відрізняється від германського в частині домінування почуттів і уявлень, часто ж більшим прагненням до суспільного ...» [1, c. 239].

Наведена розлога цитата свідчить, на наш погляд, не лише про різницю в уявленнях слов' янських і німецьких учених на походження слов'янських народів, але й про те, що поляки і русичі здавна були самостійними. Утім, утвердження їх державності, рівно як і початків державної служби, припадає на IX ст. У цей час державну службу в Київському князівстві організовували легендарні князі Ярослав, Володимир та ін., а у Князівстві Польському - князь Мешко I, Болеслав Хоробрий, Мєшко II, Каземір та ін. [21, р. 3-7], і до модерних систем управління державною службою в Україні та Польщі в XXI ст.

Князь міг одноособово вирішувати всі питання державного життя, у тому числі призначати адміністрацію (десятників, сотників та тисячників). Двір князя (як владний інститут) здійснював управління економічними, культурними, релігійними процесами, i для виконання цих функцій налічував близько сотні осіб. Слід зазначити, що державний апарат Великого князівства Литовського, у складі якого перебувала частина українських земель, був достатньо специфічним. Як і в Київській Русі, князь управляв державними справами через дружину, до складу якої входила земельна аристократія. Однак, розширення меж князівства та входження ряду нових земель призвело до потреби в модернізації та ускладненні державного апарату.

Дружина трансформувалась у князівський двір, за межі якого державний апарат не виходив протягом XIV століття. Першими посадовцями, які з'явились у 
структурі двору, були воєводи (військові керівники) та тівунки (управляли волостями), а також канщеляристи (писарі та скарбники). Зі скасуванням удільних князівств та утворенням областей і воєводств, на їх заміну було запроваджено посади старост та воєвод, які виконували не лише військові функції, а згодом засновано посади двірських, маршалків, чашників, хорунжих тощо. Найвищою військовою владою (після князя) був наділений гетьман, якому довірялось керівництво військом під час походу. Зазначені посади були багатофункціональними, тобто одна особа могла одночасно обіймати декілька посад. Для контролю збору податків та організації будівництва й підтримки в належному стані шляхів та укріплень в належному стані в межах областей було запроваджено посади намісників, городничих, каштелянів тощо.

Уникаючи розкриття генезису та еволюції державної служби в Україні та Польщі, що заслуговує на своє самостійне дослідження, зауважимо, що утвердження національних систем державної служби, у їх сучасному розумінні, і в Україні, і в Польщі відбулося на поч. ст. XX ст., після відродження нашої державності. Нині ж реформи публічної Польщі, яка є членом ЄС, є добрим прикладом для України у іï інтеграційних процесах.

Отже, основними ж періодами становлення та розвитку систем управління державною службою в Україні та Польщі є:

- периий період (IX ст. - XIII ст.) - утвердження системи управління державною службою в Київському та Польському князівствах;

- другий період (XIII ст. - XIV ст.) - занепад інститутів державності в Київському князівстві за часів Орди, розвиток Галицько-Волинського князівства і утворення Великого Князівства Литовського, де була започаткована феодально-васальна модель управління державною службою;

- третій період (XIV ст. - XVIII ст.) - становлення та розвиток управління державною службою за часів утворення Литовсько-Польської унії, а з 1569 р., після Люблінської унії, - Речі Посполитої, а також утвердження феномену Козацької держави та закріплення основ публічної служби в Конституції Пилипа Орлика 1710 р.;

- четвертий період (XVIII ст. поч. XX ст.) - перебування Українських і Польських земель у складі Російської та Австро-Угорської імперії та насадження аристократичних і дискримінаційних щодо корінного населення систем управління державною службою, заснованих на законодавстві відповідних метрополій;

- n'ятий період (поч. XX ст. - сер. XX ст.) - зародження національних систем управління державною службою за доби національно-визвольних змагань УНРЗУНР 1917-1922 та за часів відродження II Речі Посполитої в Полыщі (1918-1939 рр.);

- шостий період (перша пол. XX ст. - кін. XX ст.) - запровадження радянської державно-партійної системи управління публічною службою в Україні (1922 р.) і запровадження комуністичної моделі публічної служби в Польській Народній Республіці після Другої світової війни;

- съомий період (кін. XX ст. - поч. XXI ст.) - відродження національних систем управління державною службою після «оксамитової революції» в Польщі і за часів III Речі Посполитої та після проголошення незалежності України в 1991 році; поява 
перших законів про державну (цивільну) службу в Україні (1993 р. [13]) і Польщі (1998 p.);

- восьмий період (з поч. XXI ст. - до сьогодні) - реформування системи управління державною (цивільною) службою на цінностях Об'єднаної Свропи і прийняття нових законів про державну (цивільну) службу в Полыщі (2008 p.

Зазначимо, що для кожної держави світу властива своя модель публічної служби, а також система управління публічною, зокрема державною службою. Водночас, у держав, які мають споріднені правові та адміністративно-управлінські системи, спільні аспекти генезису та еволюціонування державотворення й правотворення, публічного управління та публічної служби, а також подібні проблеми у сфері публічної служби і наближені шляхи щодо їх вирішення, системи управління державною службою також мають схожий характер. Наглядним прикладом цього є системи управління державною службою в Україні та цивільною службою в Республіці Полыща.

Із урахуванням нормативного змісту ст. 12 чинного Закону України «Про державну службу» [12], під системою органів управління державною службою в Україні слід розуміти систему законодавчо визначених та ієрархічно упорядкованих суб'єктів державного управління із загальною (Кабінет Міністрів України) та спеціальною (центральний орган виконавчої влади, що забезпечує формування та реалізує державну політику у сфері державної служби; Комісію з питань вищого корпусу державної служби та відповідні конкурсні комісії; керівників державної служби; служби управління персоналом) компетенцією, а також профільних навчальних закладів (Національна академія державного управління при Президентові України і ін.) і наукових установ, та систему їх унормованих і взаємозумовлених функцій і повноважень, які забезпечують формування, оновлення та функціонування корпусу державних службовців в Україні.

Натомість, у Республіці Польща система управління державною (цивільною) службою подібна до української та репрезентована наступними суб'єктами, охарактеризованими в наших попередніх публікаціях [18, с. 209-210]:

- Головою Служби Цивільної (Szef Stużby Cywilnej), який підпорядкований безпосередньо Голові Ради Міністрів Польщі, шо «е керівником працівників урядової адміністрації» (п. 7 ст. 148 Конституції Польщі) і призначається і звільняється урядом, формує та реалізує державну кадрову політику та здійснює управління цивільною службою в Польщі;

- Радою Служби Цивільної (Rada Stużby Publicznej) при Голові Ради Міністрів у складі 15 членів, як консультативно-дорадчий орган у справах, пов'язаних із підготовкою стратегії управління людськими ресурсами на цивільній службі, підготовки законопроєктів і проєктів інших нормативно-правових актів і програм у сфері цивільної служби, бюджетних запитів для фінансування проходження цивільної служби, кваліфікаційних вимог для кандидатів на посади цивільної служби, а також питаннями етичної та дисциплінарної відповідальності державних службовців тощо. Забезпечення діяльності цієї Ради здійснює Канщелярія Голови Ради Міністрів Польщі; 
- генеральним директором урядовим (Dyrektor generalny urzędu), посада якого утворюється в Канцелярії Ради Міністрів, міністерствах і урядових комітетах, центральних органах виконавчої влади і в урядах воєводств, а також в Управлінні 3 реєстрації лікарських засобів, медичних приладів і біологічних продуктів та Бюро лісового насінництва. Генеральний директор підпорядковується керівникові відповідного органу виконавчої влади. Посади генерального директора не створюються в Головній Комендатурі Поліції, Головній Комендатурі Державної пожежної служби і Комендатурі Прикордонної охорони;

- керівником департаменту чи відділу (kieruyuchim departamentem lub komórką) в Канцелярії Ради Міністрів, міністерствах і урядових комітетах, центральних органах виконавчої влади і в урядах воєводств;

- Державна школа адміністрації публічної ім. Президента Республіки Польської Леха Качинського (Krajowej Szkoty Administracji Publicznej im. Prezydenta Rzeczypospolitej Polskiej Lecha Kaczyńskiego, KSAP), що здійснює професійну підготовку, перепідготовку та підвищення кваліфікації цивільних (державних) службовців у Польщі.

Ця система стала інструментом і результатом складного процесу творення цивільної служби в ІІІ Речі Посполитій. Феноменологія «творення служби цивільної» в Республіці Польща полягає в тому, що, починаючи із 1998 року, було створену нову «службу цивільну» (поряд із нею виділяють іще два складники публічної служби (служба в органах місцевого самоврядування («stużba samorzadowa») та військову й парамілітарну службу («stużba mundurowa»)), а також сформовано збалансовану систему формування державної кадрової політики й управління державною службою, що загалом сприяло інтеграції Полыщі до єдиного європейського адміністративного простору та, врешті, у 2008 році, стати державою-членом СС.

Успіхи реформування системи управління державною службою в Україні, 3 урахуванням польського досвіду, у 2014-2019 рр. відкрив для України аналогічні перспективи щодо євроінтеграції, але на сьогодні реформа державної служби потребує свого завершення, без компромісів в частині «карантинних процедур». Тим білыше, за умов поширення практики складання державних іспитів і захисту дисертацій в Україні через програмні додатки Zoom й інші, що використовуються в глобальній мережі Інтернет.

До того ж, розвиток системи управління державною службою в Україні у 2019-2020 роках демонструє неоднозначні тенденції, які віддаляють модель державної служби в Україні не лише від Польщі, а й від СС в цілому. До цих «зворотних трансформацій» слід віднести такі : безпідставне зволікання Парламенту з прийняттям нового Закону України «Про службу в органах місцевого самоврядування», який повинен був прийнятий одночасно із Законом України «Про державну службу» в 2015 рощі; відсутність глобальних міжнародних донорських проектів по реформуванню державної служби в Україні; послаблення позищій Комісії 3 питань вищого корпусу державної служби та їі «вимушене безробіття» під час пандемії COVID-19 упродовж 2020 року; відтік представників інститутів громадянського суспільства з кадрових комісії; запровадження в законодавство новели, коли конкурсний відбір проходить «не більще п'яти осіб на одну посаду» (ч.1 ст. 28 Закону 
України «Про державну службу»); повсюдність кадрових призначень на посади категорії «A» $\mathrm{i}$ «Б» $\mathrm{y}$ «коронавірусному» режимі, без конкурсів; передання Національної академії державного управління при Президентові України до відання Міністерства освіти і науки України й ін. Однак, ці «зворотні трансформації» не є фатальними i, на наш погляд, підлягають конструктивному вирішенню. Зокрема, з урахуванням позитивного досвіду творення цивільної служби в Польщі.

Чим же схожі та відмінні між собою досліджувані системи управління державною службою? Українська та польська системи органів управління державною (цивільною) службою схожі, але не тотожні. Вони мають ієрархічну побудову та, по суті, утворюють управлінську вертикаль «кадрової влади». Ці системи, у їх широкому сенсі, репрезентовані: а) парламентами, які на законодавчому рівні регулюють інститут державної служби; б) органами виконавчої влади загальної (уряд, голова уряду) та спеціальної компетенції (комісії з питань державної служби, спеціально уповноважені органи або посадові особи із питань регулювання державної служби; керівники державної служби (державні секретарі, генеральні директори; кадрові служби (департаменти) і відділи). Водночас, на відміну від України, система управління державною службою в Польщі концентрована насамперед у Голови Ради Міністрів Республіки Польщі, при якому формується та працює Рада Служби Цивільної, та у Голови Служби Цивільної, який підпорядковується безпосередньо прем'єр-міністрові. Натомість, в Україні центральним суб'єктом управління державної служби є Національне агентство України з питань державної служби, яке підпорядковане безпосередньо Кабінету Міністрів України і забезпечує діяльність Комісії з питань вищого корпусу державної служби. На наш погляд, польська модель, за якої центральним суб'єктом управління державної служби є Голова Служби Цивільної, може бути перспективною й для України, з огляду на усталеність правового управлінського статусу одноособового керівника державної служби, який призначається та звільняється урядом.

Також у Польщі маємо завершену та уніфіковану вертикаль «кадрової влади», коли генеральні директори урядові є очільниками цивільної служби в усій системі органів виконавчої влади - від Канцелярії Ради Міністрів Республіки Польща до центральних органів виконавчої влади і воєводств. Натомість в Україні державні секретарі діють у Секретаріаті Кабінету Міністрів України та міністерствах, тоді як керівниками державної служби в інших центральних органах виконавчої влади (державних службах, державних інспекціях, державних агентствах і ЦОВВ зі спеціальним статусом) є самі керівники цих ЦОВВ. Таким чином, зміна керівника ЦОВВ, як правило, несе докорінні зміни в кадровій політиці й управлінні державною службою у відомствах.

Зауважимо також, що важливим компонентом системи реалізації та формування державної кадрової політики та управління державною службою в Польщі є Державна школа адміністрації публічної ім. Президента Республіки Польської Леха Качинського (KSAP), випускники якої, завдяки набутій спеціальній професійній підготовці, мають преференції щодо обіймання вакантних посад цивільної служби. Натомість в Україні, після передачі до МОН Украӥни в листопаді 2020 року Національної академії державного управління при Президентові України 
(НАДУ), питання про суб'єкта (суб'єктів) забезпечення підготовки, перепідготовки, спеціалізації та підвищення кваліфікації державних службовців вимагає свого конструктивного розв'язання.

Висновок. Отже, основними шляхами і напрямами подальшого реформування системи управління у сфері державної служби в Україні є: а) посилення інтеграції вітчизняної моделі державної служби і механізмів управління в цій сфері до стандартів єдиного адміністративного простору в межах реалізації Угоди про асоціацію України з Європейським Союзом; б) проведення системного аудиту, із залученням міжнародного інструментарію оцінки SIGMA (Support for Improvement in Governance and Management) й ін., основних здобутків і прорахунків реформи державної служби, проведеної в Україні в 2015-2020 роках, а також визначення перспектив модернізації системи управління державної служби в Україні на наступні три роки; в) здійснення функціонального обстеження основних складників системи управління державною службою в Украӥні та забезпечення обговорення його результатів із громадськістю, а також повернення громадськості до конкурсних комісій, які визначають переможців на вакантні посади державної служби; г) посилення державно-управлінського статусу і гарантій незалежності Комісії з питань вищого корпусу державної служби, переіменувавши ії як Комісію з питань вищого корпусу державної служби при Прем'єр-міністрові України; г) скасування сумнівних новел щодо визначення переможцями «не більше п'яти осіб на одну посаду» (ч. 1 ст. 28 Закону України «Про державну службу») і призупинення дії положень цього ж Закону під час карантину, викликаного пандемією коронавірусу COVID- 19, «y частині проведення конкурсів на посади державної служби та призначення на посади державноі служби за результатами конкурсу», як такі, що, по суті, згорнули транспарентний характер реформи державної служби і суттєво послабили систему управління державною службою в Україні та ін.

\section{Використані джерела:}

1. Аренс Г. Юридическая энциклопедия. Л. Философия права, философский обзор истории права и история положительного права у народов Востока, Греков, Римлян, Германщев и других Европейских народов / пер. с нем. Москва: В типографии А. Семена, 1862. IV с., 524 с.

2. Білинська М. М. Кадрова політика і державна служба [Текст] : конспект лекцій / М. М. Білинська, О. Л. Євмешкіна, І. Г. Сурай ; Нац. акад. держ. упр. при Президентові Украӥни, Упр. орг. фундам. та приклад. дослідж., Каф. держ. упр. і менедж. Київ : НАДУ, 2012. 72 c.

3. В ЄС розчаровані, що Рада не відновила конкурсний набір на держслужбу / Українська правда: URL: https://www.pravda.com.ua/news/2020/12/16/7277207/. (дата звернення: 06.12.2020)

4. Денисов М. Д. Становлення і розвиток державної служби в країнах Східної Європи. Публічне управління та митне адміністрування. 2016. № 1(14). С. 108-116.

5. Державна служба і кадрова політика: наук. розробка / [авт. кол.: Р. В. Войтович, В. В. Карлова, А. П. Рачинський та ін.]; за заг. ред. Р. В. Войтович. Київ : НАДУ, 2015. 56 с.

6. Дубенко С. Д. Державна служба і державні службовці в Україні: навч.-метод. посіб.; за заг. ред. Н. Р. Нижник. Київ : Ін Юре, 1999. 244 с. 
7. Загоскин Н. Очерки организации и происхождения служилого сословия в допетровской Руси. Казань : В Университ. Типограф., 1875. 223 с.

8. Красівський Д. О. Впровадження європейських стандартів кадрових забезпечення політичного управління: польський досвід. Економіка і держава. Серія «Державне управління». 2017. № 1. С. 6-9.

9. Малюга А. Право громадян на державну службу в Україні: поняття, законодавче забезпечення, вимоги та обмеження до кандидатів. Вісник НАДУ при Президентові України. (Серія «Державне управління»). 2018. № 1. С. 38-44.

10. Неліпа Д. В. Організаційно-правові засади державної служби в Україні [текст] Навч. посібн. Київ : «Центр учбової літератури», 2012. 368 с.

11. Ольшевский Л. Бюрократия. Москва : Издание В. М. Сабина, 1906. 417 с.

12. Про державну службу: Закон України від 10 грудня 2015 р. Відомості Верховної Ради Украӥни. 2016. № 4. Ст. 43.

13. Про державну службу: Закон України від 16 грудня 1993 р. № 3723-XII. Відомості Верховної Ради України. 1993. № 52. Ст. 490.

14. Проскуряков К. С. Європейські стандарти державної служби: досвід Польської Республіки. Вісник Київського національного університету імені Тараса Шевченка. 2014. Вип. 1. C. $69-72$.

15. Професіоналізація у сфері публічного управління: стан, проблеми, перспективи вирішення : Сучасний контент професійного розвитку менеджерів освіти в умовах реформування освітньої галузі : монографія / [Хаджирадєва С. К., Воронова С. В., Кравцова Н. Є. та ін.]; за заг. ред. С. К. Хаджирадєвої. Ч. ІІ. Миколаїв : Ємельянова Т. В., 2017. 165 c.

16. Пухкал О. Г. Теоретико-методологічні підходи визначення сутності поняття публічного управління / О. Г. Пухкал, І. В. Тютюнник. Інвестиції: практика та досвід. 2015. № 18. С. 93-97.

17. Сборник распоряжений Графа Михаила Николаевеча Муравьева по усмирению Польского мятежа в Северо-Западных губерний 1863-1864. Составитель Н. Цылов. Вильно: Типограф. А. Киркора и братьев Роммов, 1866. 383 с. IV с.

18. Федоренко В. Л., Федоренко М. В. Системи управління державною службою в Україні та Польщі: порівняльно-правовий аспект. Вісник Луганського держ. університету Внутр. справ ім. Е. О. Дідоренка. 2020. № 3 (91). С. 205-217.

19. Щодо процедури тимчасового добору на державну службу на період карантину / Нац. агентство з питань державної служби. URL: bit.ly/2L3FM9E.

20. Bossaert D., Demmke Ch. Służba cywilna w państwach akcesyjnych. Tendencje i wpływ procesów integracyjnych. Łódź: Instytut Europejski, 2003. 317 s.

21. Goldryng H. Skrócony podręcznik historji Polski. Podług Prof. Dr. Anatola Lewickiego. Wydanie III, Łódź: Nakładem A.F. Mitytlera, 1928. 96 s.

22. Habermas J., Strukturalne przeobrażenia sfery publicznej, Warszawa: Wydawnictwo Naukowe PWN, 2008. 458 s.

23. Kudrycka B. (red.). Rozwój kadr administracji publicznej. Białystok: Wydawnictwo Uniwersytetu w Białymstoku, 2001. $176 \mathrm{~s}$.

24. Nesterovych, V. (2015). EU Standards for the Regulation of Lobbying. Prawa Człowieka, 1: 97-107.

25. Nesterovych, V. (2016). International standards for the regulation of lobbying (EU, CE, OECD, CIS). Krytyka Prawa, 8(2): 79-101. 
26. Przywora B. Transformacje ustrojowe polskiej służby cywilnej. Wydanie I. Kraków: Wydawnictwo Uniwersytetu Jagiellońskiego, 2012. $301 \mathrm{~s}$.

27. O służbie cywilnej: Ustawa z dnia 21 listopada 2008 r. (Dz. U. z 2020 r. poz. 265, z późn. zm.) /Sejm Rzeczypospolitej Polskiej. URL : https:/ / bit.ly/3rEfH1N.pdf.

\section{References:}

1. Arens, H. (1862) Yurydycheskaya éntsyklopedyya. L. Fylosofyya prava, fylosofskyy obzor ystoryy prava y ystoryya polozhytel'noho prava u narodov Vostoka, Hrekov, Rymlyan, Hermantsev y druhykh Evropeyskykh narodov. Per. s nem. Moskva: V typohrafyy A. Semena. [in Russian].

2. Bilyns'ka, M.M . (2012) Kadrova polityka i derzhavna sluzhba [Tekst] : konspekt lektsiy. M. M. Bilyns'ka, O. L. Yevmeshkina, I. H. Suray (Eds.) ; Nats. akad. derzh. upr. pry Prezydentovi Ukrayiny, Upr. orh. fundam. ta pryklad. doslidzh., Kaf. derzh. upr. i menedzh. Kyiv : NADU. [in Ukrainian].

3. V YES rozcharovani, shcho Rada ne vidnovyla konkursnyy nabir na derzhsluzhbu/ Ukrayins'ka Pravda - Ukrainian Pravda: N. d. N. p. URL : https://www.pravda.com.ua/ news/ 2020/12/16/7277207. [in Ukrainian].

4. Denysov, M. D. (2016) Stanovlennya i rozvytok derzhavnoyi sluzhby v krayinakh Skhidnoyi Yevropy. Publichne upravlinnya ta mytne administruvanny - Public administration and customs administration, 1(14), 108-116. [in Ukrainian].

5. Derzhavna sluzhba i kadrova polityka: nauk. rozrobka (2015) R. V. Voytovych, V. V. Karlova, A. P. Rachyns'kyy (Eds.) et al.; R. V. Voytovych (Ed.). K yiv : NADU. [in Ukrainian].

6. Dubenko, S. D. (1999) Derzhavna sluzhba i derzhavni sluzhbovtsi v Ukrayini: navch.metod. posib. N. R. Nyzhnyk (Ed.). Kyiv : In Yure. [in Ukrainian].

7. Zahoskyn, N. (1875) Ocherky orhanyzatsyy y proyskhozhdenyya sluzhyloho soslovyya v dopetrovskoy Rusy. Kazan' : V Unyversyt. Typohraf. [in Russian].

8. Krasivs'kyy, D. O. (2017) Vprovadzhennya yevropeys'kykh standartiv kadrovykh zabezpechennya politychnoho upravlinnya: pol's'kyy dosvid. Ekonomika i derzhava. Seriya «Derzhavne upravlinnya» - Economy and state. Public Administration Series, 1, 6-9. [in Ukrainian].

9. Malyuha, A. (2018) Pravo hromadyan na derzhavnu sluzhbu v Ukrayini: ponyattya, zakonodavche zabezpechennya, vymohy ta obmezhennya do kandydativ. Visnyk NADU pry Prezydentovi Ukrayiny. Economy and state. - NAPA Bulletin under the President of Ukraine. (Series "Public Administration"), 1, 38-44. [in Ukrainian].

10. Nelipa, D. V. (2012) Orhanizatsiyno-pravovi zasady derzhavnoyi sluzhby v Ukrayini [tekst] : navch. posibn. Kyiv : «Tsentr uchbovoyi literatury». [in Ukrainian].

11. Ol'shevskyy, L. (1906) Byurokratyya. Moskva : Yzdanye V. M. Sabyna. [in Russian].

12. Pro derzhavnu sluzhbu: Zakon Ukrayiny vid 10 hrudnya 2015 r. (2015) Vidomosti Verkhovnoyi Rady Ukrayiny - Information of the Verkhoona Rada of Ukraine, 4, art. 43. [in Ukrainian].

13. Pro derzhavnu sluzhbu: Zakon Ukrayiny vid 16 hrudnya 1993 r. № 3723-XII (1993) Vidomosti Verkhovnoyi Rady Ukrayiny - Information of the Verkhovna Rada of Ukraine, 52, art. 490. [in Ukrainian].

14. Proskuryakov, K. S. (2014) Yevropeys'ki standarty derzhavnoyi sluzhby: dosvid Pol's'koyi Respubliky. Visnyk Kyyivs'koho natsional'noho universytetu imeni Tarasa Shevchenka Bulletin of Taras Shevchenko National University of Kyiv, 1, 69-72. [in Ukrainian].

15. Profesionalizatsiya u sferi publichnoho upravlinnya: stan, problemy, perspektyvy vyrishennya : Suchasnyy kontent profesiynoho rozvytku menedzheriv osvity v umovakh reformuvannya osvitn'oyi haluzi : monohrafiya (2017) / Khadzhyradyeva S. K., Voronova S. V., 
Kravtsova N. YE. et al. ; S. K. Khadzhyradyeva (Ed.). Part. 2. Mykolayiv : Yemel'yanova T. V. [in Ukrainian].

16. Pukhkal, O. H. (2015) Teoretyko-metodolohichni pidkhody vyznachennya sutnosti ponyattya publichnoho upravlinnya / O. H. Pukhkal, I. V. Tyutyunnyk. Investytsiyi : praktyka ta dosvid - Investments: practice and experience, 18, 93-97. [in Ukrainian].

17. Sbornyk rasporyazhenyy Hrafa Mykhayla Nykolaevecha Murav'eva po usmyrenyyu Pol'skoho myatezha v Severo-Zapadnykh hubernyy 1863-1864 (1866). N. TSylov (Ed.). Vyl'no : Typohraf. A. Kyrkora y brat'ev Rommov. [in Russian].

18. Fedorenko, V. L., Fedorenko, M. V. (2020) Cystemy upravlinnya derzhavnoyu sluzhboyu v Ukrayini ta Pol'shchi: porivnyal'no-pravovyy aspekt. Visnyk Luhans'koho derzh. universytetu vnutr. sprav im. E. O. Didorenka-Bulletin of the Luhansk state. University of Internal Affairs after E. Didorenko, 3 (91), 205-217. [in Ukrainian].

19. Shchodo protsedury tymchasovoho doboru na derzhavnu sluzhbu na period karantynu. Natsional'ne ahenstvo z pytan' derzhavnoyi sluzhby - Nat. civil service agency. N. d. N. p. URL : https:// bit.ly/2L3FM9E. [in Ukrainian].

20. Bossaert, D., Demmke, Ch. (2003) Służba cywilna w państwach akcesyjnych. Tendencje i wpływ procesów integracyjnych. Łódź : Instytut Europejski. [in Polish].

21. Goldryng, H. (1928) Skrócony podręcznik historji Polski. Podług Prof. Dr. Anatola Lewickiego. Wydanie III, Łódź : Nakładem A. F. Mitytlera. [in Polish].

22. Habermas, J., (2008) Strukturalne przeobrażenia sfery publicznej, Warszawa : Wydawnictwo Naukowe PWN. [in Polish].

23. Kudrycka, B. (red.). (2001) Rozwój kadr administracji publicznej. Białystok,: Wydawnictwo Uniwersytetu w Białymstoku. [in Polish].

24. Nesterovych, V. (2015). EU Standards for the Regulation of Lobbying. Prawa Człowieka, 1: 97-107. [in English].

25. Nesterovych, V. (2016). International standards for the regulation of lobbying (EU, CE, OECD, CIS). Krytyka Prawa, 8(2): 79-101. [in English].

26. Przywora, B. (2012) Transformacje ustrojowe polskiej służby cywilnej. Wydanie I. Kraków: Wydawnictwo Uniwersytetu Jagiellońskiego. [in Polish].

27. O służbie cywilnej: Ustawa z dnia 21 listopada 2008 r. (Dz. U. z 2020 r. poz. 265, z późn. zm.) / Sejm Rzeczypospolitej Polskiej. URL : bit.ly/3rEfH1N. [in Polish].

Стаття надійшла до редколегіï 06.12.2020

Федоренко М. В., соискатель степени высшего образования «магистр» Национальной академии государственного управления при Президенте Украины (г. Киев, Украина)

\section{УТВЕРЖДЕНИЕ, РАЗВИТИЕ И ОСНОВНЫЕ НАПРАВЛЕНИЯ СОВЕРШЕНСТВОВАНИЯ СИСТЕМ УПРАВЛЕНИЯ ГОСУДАРСТВЕННОЙ СЛУЖБОЙ В УКРАИНЕ И РЕСПУБЛИКЕ ПОЛЬША}

В статье раскрывается сущность, содержание и особенности построения и функционирования системы управления государственной (публичной) службы в Украине и в Республике Полыша в трансформационный период. Систематизируется положительный 
опыт моделирования эффективной системы управления публичной (гражданской) службы в Польше, который может быть использован в Украине для решения проблем. Раскрывается генезис и эволюция института управления государственной службой в Украине, а также содержание и особенности трансформации системы управления государственной службы в контексте проведения реформы публичной службы в 2015-2020 годах. Осуществляется сравнение и анализ правового и управленческого статуса основных элементов (субъектов) системы управления государственной службой в Украине и Республике Польша. Анализируется назначения центров (школ, академий) для профессиональной подготовки, переподготовки, специализации и повьшения квалификации государственных служащих в Украине и Польше на примере Национальной академии государственного управления при Президенте Украины (НАГУ) и Государственной школы администрации публичной им. Президента Республики Польской Леха Качиньского.

Ключевые слова: государственная служба, гражданская служба, система управления государственной службой, реформа государственной службы.

Fedorenko M.,

Master's degree Student of the National Academy of Public Administration under the President of Ukraine

(Kyiv, Ukraine)

\section{APPROVAL, DEVELOPMENT AND MAIN DIRECTIONS OF IMPROVEMENT OF CIVIL SERVICE MANAGEMENT SYSTEMS IN UKRAINE AND THE REPUBLIC OF POLAND}

The article reveals the essence, content and features of the construction and operation of the management system of the civil (public) service in Ukraine and in the Republic of Poland in the transformation period. The positive experience of modeling an effective public (civil) service management system in Poland, which can be used in Ukraine to solve problems, is systematized. The genesis and evolution of the institution of civil service management in Ukraine, as well as the content and features of the transformation of the civil service management system in the context of public service reform in 2015-2020 are revealed. The comparison and analysis of the legal and administrative status of the main elements (subjects) of the civil service management system in Ukraine and the Republic of Poland is carried out. The purpose of centers (schools, academies) for professional training, retraining, specialization and advanced training of civil servants in Ukraine and Poland is analyzed on the example of the National Academy of Public Administration under the President of Ukraine (NAPA) and the State School of Public Administration. President of the Republic of Poland Lech Kaczynski (KSAP). It is concluded that the main ways and directions of further reforming the management system in the civil service in Ukraine are to strengthen the integration of the domestic model of civil service and management mechanisms in this area to the standards of a single administrative space within the Association Agreement between Ukraine and the European Union. functional review of the main components of the civil service management system in Ukraine and ensuring the discussion of its results with the public, as well as the return of the public to the competition commissions, which determine the winners for vacant civil service positions.

Keywords: civil service, civil service, civil service management system, civil service reform. 